\title{
Pembaharuan Hukum Pidana Tentang Pertanggungjawaban Pidana Terhadap Pengguna Jasa Prostitusi Di Indonesia
}

\author{
Kania Mulia Utami; Ridwan; Aan Asphianto \\ Fakultas Hukum, Universitas Sultan Ageng Tirtayasa \\ Author's Email Correspondence: kaniamuliau@gmail.com
}

\begin{abstract}
ABSTRAK
Penelitian ini bertujuan untuk untuk membahas tentang pertanggungjawaban pidana terhadap pengguna jasa prostitusi dalam perspektir perbandingan Indonesia dan Swedia. Tipe penelitian ini adalah penelitian normatif. Hasil Penelitian ini menghasilkan kesimpulan bahwa menurut hukum positif di Indonesia tidak adanya pertanggungjawaban pidana yang dapat menjerat pengguna jasa prostitusi secara jelas dan tegas sehingga belum efektif dan menyebabkan tidak maksimalnya dalam penanggulangan prostitusi itu sendiri. Apabila tidak ada aturan hukum di indonesia yang mengatur tentang pengguna jasa prostitusi, maka para pengguna jasa prostitusi akan merasa aman dan tetap leluasa membeli jasa untuk kepuasan mereka semata. Berbeda dengan kebijakan hukum di Swedia yang sudah memiliki aturan yang dapat menjerat hukum terhadap pengguna jasa prostitusi. Pertanggungjawaban pidana dalam hal ini sangatlah diperlukan pengaturan yang jelas dan tegas, oleh karena itu diperlukan pembaharuan hukum pidana terkait pertanggungjawaban pidana bagi para pengguna jasa prostitusi di Indonesia.
\end{abstract}

Kata Kunci: Pembaharuan Hukum, Pertanggungjawaban Pidana, Pengguna Jasa, Prostitusi.

\section{ARTICLE HISTORY}

Submission: 2020-03-27

Accepted: 2020-09-29

Publish: 2020-10-10

KEYWORDS: Criminal LaW Reform, Criminal Liability, Service Users, Prostitution.

\begin{abstract}
This article aims to discuss criminal liability on prostitution clients criminal liability in a comparative study between indonesia and swedish. This research is normative. The result of this study lead to the conclusion that based on the positive law in Indonesia there is no criminal liability that can ensnare the users of prostitution service clearly and decisively so there is not effective and not too optimum of handling prostitution. If there is no legal rule in Indonesia that regulates the users of prostitution services, then the users of prostitution services will feel safe and remain free to buy services for their satisfaction. Unlike the legal policy in Sweden which already has rules that can ensnare the law against prostitution service users. Criminal liability in this case is clearly and strictly needed, therefore, criminal law reform is needed related to criminal liability for users of prostitution services in Indonesia.
\end{abstract}

\section{A. PENDAHULUAN}

Kehidupan bermasyarakat ini memang selalu menjadi masalah-masalah sosial yang terus berkembang sejalan dengan perkembangan zaman, terutama yang berkaitan dengan masalah prostitusi. Fenomena prostitusi bukanlah hal yang baru 
dalam kehidupan masyarakat. Sejak dahulu sampai sekarang praktik prostitusi sudah ada. Hingga saat ini prostitusi telah berkembang seiring sejarah umat manusia yang panjang dari masa ke masa. Dari masa ke masa itu pula prostitusi dianggap sebagai suatu masalah sosial yang dianggap menyimpang dan dapat berdampak negatif terhadap masyarakat.

Hal ini selaras dengan pandangan Dennis Winn bahwa sederhananya, pelacuran dalam sudut pandang kriminologi, adat, agama, disitulah lahir pemikiran sebagai gejala sosial. Pelacuran bisa mendatangkan penyakit kelamin (Herpes Genital, Sifilis, Gonore, Klamidia, HIV/AIDS), menghancurkan rumah tangga, bahkan cenderung memicu kekerasan. ${ }^{1}$ Pelacuran adalah sebuah aktivitas yang terdapat ketentuan yang dapat diidentifikasi yakni pertukaran antara uang dengan seks. Maka menurut AS Alam bahwa:

Pelacuran bertentangan dengan definisi sosiologi dari kejahatan (Sociological Definition of Crimse), karena dikategorikan sebagai perbuatan jahat yang bertentangan dan melanggar norma-norma dalam kehidupan bermasyarakat karena tidak hanya dilarang oleh norma hukum dan norma agama saja, tetapi juga bertentangan dengan (norma) kesusilaan dalam setiap hati nurani manusia. $^{2}$

Selain Prostitusi suatu masalah sosial yang dianggap menyimpang dan berdampak negatif terhadap masyarakat, Kartini Kartono beranggapan bahwa :

Prostitusi juga merupakan salah satu bentuk penyakit masyarakat yang harus diberhentikan penyebarannya. Tanpa mengabaikan usaha pencegahan dan perbaikannya. Pelacuran atau Prostitusi berasal dari bahasa Latin pro-stituere atau pro-stauree, yang berarti membiarkan diri berbuat zina, melakukan persundalan, pencabulan, dan pergendakan. Sedang prostitute adalah pelacur atau sundal. Dikenal dengan istilah WTS atau wanita tunasila. Maka pelacur itu adalah wanita yang tidak pantas kelakuannya dan bisa mendatangkan mala/celaka dan penyakit, baik kepada orang lain yang bergaul dengan dirinya, maupun kepada diri sendiri. ${ }^{3}$

Soedjono D, mengemukakan bahwa :

Di Indonesia istilah prostitusi dikenal dengan "pelacuran" yang pada umumnya dirumuskan demikian: "pelacuran" dapat diartikan sebagai penyerahan badan wanita dengan pembayaran, kepada orang laki-laki guna pemuasan nafsu sexual orang-orang itu. Di Eropah sering disebut adanya "pelacuran laki-laki" (yang bersedia memuaskan wanita-wanita kesepian). Tetapi hal ini tidak umum di Asia dan Indonesia. 4

Berdasarkan uraian di atas, dapat disimpulkan bahwa prostitusi dapat mengganggu, merugikan keselamatan, ketentraman dan kemakmuran baik jasmani dan rohani maupun sosial dari kehidupan masyarakat secara umum. Hal ini karena prostitusi melanggar adat istiadat dan norma yang berlaku di masyarakat, yaitu norma kesopanan, norma kesusilaan, norma agama dan norma hukum.

A.S Alam dan Amir Ilyas, Kriminologi Suatu Pengantar, Kencana, Jakarta, 2018, hlm. 112.

Lucky Elza Aditya, Urgensi Kriminalisasi Terhadap Pelacuran dalam Pembaharuan Hukum Pidana di Indonesia, Jurnal Hukum, 2016, hlm. 2.

3 Kartini Kartono, Patologi Sosial, PT Raja Grafindo Persada, Jakarta, 2005, hlm. 207.

4 Leden Marpaung, Kejahatan Terhadap Kesusilaan Dan Masalah Prevensinya, Sinar Grafika, Jakarta, 2008, hlm.7. 
Kesulitan untuk memenuhi kebutuhan bagi segelintir wanita yang tidak memiliki keterampilan (Skill), melakukan perbuatan jalan pintas dengan menjajahkan dirinya di tempat-tempat tertentu (di luar lokalisasi WTS), tampaknya menimbulkan pemandangan yang tidak berkenaan dihati.

Merton, juga berpendapat bahwa :

Struktur sosial dalam kenyataannya telah membuat orang-orang tertentu di masyarakat untuk bertindak menyimpang daripada mematuhi norma-norma sosial. Banyak faktor dalam masyarakat yang membuktikan bahwa orang miskin terdesak kebutuhan ekonomi, maka kejahatan merupakan jalan untuk mendapatkan nafkah. Dalam hal ini, menjadi PSK adalah jalan keluar untuk menghasilkan uang, baik wanita maupun pria. ${ }^{5}$

Berdasarkan uraian diatas dapat disimpulkan bahwa prostitusi merupakan permasalahan yang sangat kompleks karena menyangkut aspek sosial, gender, hukum, kesehatan, moral dan etika, agama, pendidikan, psikologis, ekonomi, industrialisasi, dan juga masalah politik.

Kasus prostitusi di Indonesia sudah banyak terjadi, beberapa contoh kasus terkait prostitusi yaitu:

Tahun 2015, dalam kasus prostitusi yang juga melibatkan sejumlah artis, sebagai muncikari Robby Abbas dijatuhi hukuman penjara 1 tahun 4 bulan sementara PSK dan pengguna bebas dari segala tuntutan. Begitu pula dengan kasus prostitusi artis di Surabaya yang melibatkan artis Vanessa Angel dan Avriellia Shaqilla, polisi langsung menetapkan muncikari sebagai tersangka. Vanessa Angel dan Avriellia Shaqilla sebelumnya berstatus hanya sebagai saksi dan korban saja, tetapi saat ini status Vanessa Angel berubah menjadi tersangka dalam kasus ini karena telah melanggar Pasal 27 ayat (1) UndangUndang Informasi Transaksi Elektronik) namun pengguna hanya menjadi saksi. ${ }^{6}$

Kasus di atas menjelaskan bahwa tidak semua pihak-pihak yang terlibat dalam prostitusi dapat dijerat oleh hukum. Karena hukum pidana positif Indonesia belum mengatur secara jelas dan tegas tentang perbuatan prostitusi baik dalam KUHP maupun Undang-Undang diluar KUHP. Aturan yang ada di Indonesia terkait prostitusi adalah :

Pengaturan dalam KUHP tentang delik-delik kesusilaan seperti pada pasal 281 sampai pasal 303, khususnya pasal 296 dan pasal 506 tidak menjerat pengguna, melainkan hanya menjerat kepada pemilik rumah bordil, mucikari dan makelar atau calo dari perbuatan pelacuran. Sedangkan Undang-Undang di luar KUHP, yakni Undang-Undang Nomor 21 Tahun 2007 tentang Pemberantasan Tindak Pidana Perdagangan Orang hanya dapat mempidana seseorang yang mendapatkan keuntungan dari perdagangan orang (mucikari). Undang-Undang Nomor 35 Tahun 2014 tentang Perubahan Atas UndangUndang Nomor 23 Tahun 2002 tentang Perlindungan Anak hanya mempidana pengguna dari eksploitasi seksual anak. ${ }^{7}$

Paisol Burlian, Patologi Sosial, PT Bumi Aksara, Jakarta, 2016, hlm. 206.

Trias Palupi Kurnianingrum, Politik Hukum Terhadap Terhadap Tindak Pidana Prostitusi, Bidang Hukum Info Singkat, Vol. XI No.01, 2019, hlm. 2.

7 Lucky Elza Aditya," Urgensi Kriminalisasi Terhadap Pelacuran",hlm. 3. 
Adapun pengaturan tentang pelacuran diatur dalam peraturan daerah setempat, akan tetapi tidak setiap daerah memiliki peraturan daerah tentang pelacuran. Penegakan hukum terhadap pelacuran melalui peraturan daerah hanya bersifat territorial karena pengaturannya berada pada peraturan daerah masing-masing sehingga menimbulkan diskriminasi, ketidakadilan dan ketidakpastian hukum karena setiap daerah memiliki budaya hukum yang berbeda-beda baik dalam pengertian pelacuran, pertanggungjawaban pidana pelacuran dan pemidanaan pelaku pelacuran. ${ }^{8}$

Prostitusi di Indonesia kian hari bertambah pesat. Hal tersebut seiring dengan banyaknya permintaan akan jasa pelayanan seksual oleh pengguna jasa prostitusi. Seseorang yang dikatakan pengguna disebut sebagai pihak yang terlibat dalam prostitusi yang bebas, artinya belum terikat pada aturan hukum positif.Sedangkan, pemerintah Indonesia tidak tegas dalam melarang adanya praktek-praktek prostitusi. Kegiatan prostitusi dapat melibatkan banyak pihak, seperti germo, para calo, pekerja seks komersial (PSK) serta pengguna jasa yang sebagian besar pelakunya merupakan laki-laki. Namun, hal ini sering luput dari perhatian aparat penegak hukum yang menyebabkan sulitnya penanggulangan prostitusi. Padahal, bertambahnya jumlah pengguna jasa prostitusi akan sejalan dengan tingkat praktek prostitusi dimasyarakat. Maka dari itu, peneliti disini hanya membatasi penelitiannya terhadap pengguna jasa prostitusi.

Berdasarkan hukum ekonomi, orang akan menyediakan jasa/barang dikarenakan adanya permintaan. Sejalan dengan hal tersebut, adanya pelacur karena ada permintaan dari pengguna jasa. Seharusnya jika ada istilah Wanita Tuna Susila (WTS) sebagai penjual layanan seks komersial harusnya juga ada istilah Pria Tuna Susila (PTS) sebagai pengguna jasa layanan seks komersial sebagai padanan yang tepat, sehingga dengan demikian baik laki-laki maupun perempuan yang terlibat dalam prostitusi mempunyai kedudukan yang sama untuk disalahkan, termasuk diberi label yang sama sebagai suatu perbuatan yang tidak bermoral.

Apabila dibandingkan dengan kebijakan negara lain, Swedia dapat menjadi contoh salah satu negara yang mengatur terkait pengguna jasa prostitusi. Seperti halnya yang dikemukakan oleh Max Waltman, bahwa:

Swedia menjadi negara pertama di dunia untuk memperkenalkan Undangundang yang mengkriminalkan pembelian layanan seksual pada 1 Januari

1999. Swedia memiliki sejarah dimana pelacur dilihat sebagai masalah, tetapi Swedia telah menyadari bahwa pelacur itu sangat sering menjadi korban yang dieksploitasi dalam pelacuran. Karena ini Swedia mengatur pembeli layanan seksual, dengan tujuan mengurangi permintaan prostitusi. Jika tidak ada permintaan, maka tidak akan ada pelacuran. ${ }^{9}$

Ketentuan hukuman larangan pembelian layanan seksual saat ini ditemukan dalam Swedish Penal Code, chapter 6: Sexual Crimes, Section 11:

8 Lucky Elza Aditya," Urgensi Kriminalisasi Terhadap Pelacuran”, hlm. 4.

9 Max Waltman, Sweden's prohiibition of purchase of sex: The law's reason, impact and potential, Departmen of political Science, Women's Studies International forum 34, 2011, hlm. 449. 
"A person who, otherwise than as previously provided in this Chapter, obtains a casual sexual relation in return for payment, shall be sentenced for purchise of sexual service to a fine or imprisonment for at most one year.

The provision of the first paragraph also apply if the payment was promised or given by another person"10

(Seseorang yang selain dari yang disebutkan sebelumnya dalam bab ini, melakukan hubungan seksual biasa dengan imbalan pembayaran, akan dihukum karena pembelian layanan seksual dengan denda atau hukuman penjara paling lama satu tahun.

Ketentuan paragraf pertama juga berlaku jika pembayaran dijanjikan atau diberikan oleh orang lain).

Berdasarkan uraian tersebut, yang dimaksud dengan seseorang yang selain dari yang disebutkan dalam bab ini adalah yang terdapat dalam Swedish Penal Code Chapter 6 section 1-10 yaitu:

Seperti pemerkosaan, pemaksaan seksusal, eksploitasi seksual terhadap anak, seseorang yang melakukan hubungan seksual dengan seorang anak dibawah umur 15 tahun, pelecehan seksual terhadap seorang anak dan pelecehan seksual berat terhadap seorang anak, seseorang yang melakukan hubungan seks dengan anaknya sendiri, eksploitasi anak untuk berpose seksual, pembelian tindakan seksual dari anak, seksual dalam penganiayaan. ${ }^{11}$

Selain itu, pelanggan WTS benar-benar dibuat jera karena jika tertangkap identitasnya akan dipublikasikan ke media massa. Tidak pandang bulu, termasuk saat sejumlah hakim Swedia tertangkap basah dalam skandal prostitusi pada tahun 2005 . Jadi selain harus membayar denda yang cukup besar atau penjara satu tahun, mereka juga dipermalukan di tengah masyarakat. Swedia juga menyediakan dana pelayanan sosial untuk membantu WTS yang ingin pensiun. Keberhasilan Swedia ini juga diadopsi Finlandia, Norwegia, Islandia, Skotlandia, dan terakhir Perancis. ${ }^{12}$

Tidak hanya di Swedia yang mengatur terkait pengguna jasa prostitusi tersebut, bahkan Negara lain seperti Finlandia. Negara Finlandia memiliki aturanterkait pengguna jasa prostitusi yang terdapat dalam The Criminal Code of Finland chapter 20, section $8 .{ }^{13}$

Selain dari Negara Swedia, Finlaindia, Perancis, pada tahun 2008 Negara Norwegia juga memiliki aturan hukum terkait pengguna jasa prostitusi, aturan tersebut terdapat dalam :

Section 316 of the Norwegian General Civil Penal Code: The law against buying sexual service. Menurut KUHP Norwegia, menjual layanan seksual adalah legal. Namun, adalah ilegal bagi warga negara Norwegia atau orang yang tinggal di Norwegia atau untuk membeli layanan seksual, baik Norwegia atau di luar

10 Swedish Penal Code, chapter 6: Sexual Crimes, Section 11.

11 Swedish Penal Code Chapter 6 section 1-10.

12 Anton R, Sudah Saatnya Pemerintah dan DPR Rumuskan RUU Anti Prostitusi, diakses dari https://www.hidayatullah.com/berita/nasional/read/2015/05/21/70066/sudah-saatnya pemerintah-dan-dpr-rumuskan-ruu-anti-prostitusi.html, pada tanggal 23 Januari 2019, pukul 14.59

13 Procon, 100 Countries and Their Prostitution Policies, https:// prostitution. procon.org/view.resource.php?resourceID=000772, pada tanggal 12 Juni 2019, pukul 12.17. 
negeri. Membeli layanan seksual dapat dihukum dengan denda dan satu tahun penjara. ${ }^{14}$

Berdasarkan uraian perbandingan diatas dapat disimpulkan bahwa pembaharuan hukum pidana terkait pertanggungjawaban pidana terhadap pengguna jasa prostitusi dirasa perlu analisis yang mendalam dan hukum positif belum memadai untuk itu. Maka dari itudengan metode perbandingan hukum, seperti kebijakan negara lain yang dapat menurunkan tingkat jumlah prostitusi karena adanya aturan yang mengatur terkait pengguna jasa prostitusi tersebut.

\section{B. METODE PENELITIAN}

Tipe penelitian ini adalah tipe normatif, yaitu penelitian yang dilakukan atau dituju hanya pada peraturan-peraturan tertulis atau bahan-bahan hukum terdiri dari bahan primer meliputi peraturan perundangan, bahan hukum sekunder terdiri dari buku, jurnal, dan literatur lainnya.

\section{PEMBAHASAN}

\section{Pertanggungjawaban Pidana terhadap Pengguna Jasa Prostitusi di Indonesia}

Pertanggungjawaban pidana dapat membedakan antara perbuatan yang dilarang dan perbuatan yang tidak dilarang dalam hukum pidana. Jika ada aturan yang dilarang oleh hukum pidana, maka dari itu perbuatan tersebut tidak boleh dilakukan. Demikian juga jika dikaitkan dengan perbuatan pengguna jasa prostitusi apakah perbuatan tersebut dilarang oleh hukum atau tidak. Jika sudah dilarang dalam hukum pidana, maka perbuatan untuk membeli seks secara komersial tidak diperbolehkan oleh hukum dan harus dipertanggungjawabkan secara pidana, sebab dengan dipertanggungjawabkanya perbuatan yang dilarang secara pidana, akan menjadi penentu syarat dapat dipidananya seseorang.

Hal ini diperkuat oleh Chairul Huda, yang menyatakan terkait aturan hukum mengenai pertanggungjawaban pidana memiliki fungsi yaitu :

Sebagai penentu syarat-syarat yang harus ada pada diri seseorang sehingga sah dijatuhi pidana. Penentu apakah seseorang patut dicela karena perbuatannya, dimana celaan tersebut adalah pemidanaan. Dengan demikian, "it operates to filter those deserving punishment for their wrong from those wo do not and to grade liability according to their degree fault". Aturan mengenai pertanggungjawaban pidana merupakan saringan pengenaan pidana, yaitu hanya dapat diterapkan terhadap mereka yang memiliki kesalahan dan pidana yang dikenakan sebatas kesalahannya tersebut. 15

Sementara itu, pertanggungjawaban pidana menjurus kepada pemidanaan petindak, jika telah melakukan suatu tindak pidana dan memenuhi unsur-unsurnya yang telah ditentukan dalam Undang-Undang. Dilihat dari sudut terjadinya suatu tindakan yang terlarang, seseorang akan dipertanggungjawab pidanakan atas

14 Procon, 100 Countries and Their Prostitution Policies.

15 Chairul Huda, "Dari 'Tiada Pidana Tanpa Kesalahan Menuju Kepada "Tiada Pertanggungjawaban Pidana Tanpa Kesalahan", Kencana, Jakarta, 2011, hlm. 17. 
tindakan-tindakan tersebut apabila tindakan tersebut bersifat melawan hukum. ${ }^{16}$ Berkenaan dengan penjelasan tersebut jika dikaitkan dengan perbuatan pengguna jasa prostitusi maka untuk dapat dipertanggungjawabkan pidana terhadap seorang pelaku harus dilihat apakah pelakunya bersalah dan adanya tindakan yang bersifat melawan hukum.

Sedangkan, untuk menentukan apakah suatu perbuatan dapat dipidana atau tidaknya, didasarkan dengan asas legalitas. Dasar pokok hukum pidana adalah asas legalitas, yaitu perbuatan tidak dapat dipidana selain atas kekuatan peraturan undangundang pidana yang terdahulu diadakan (sebelum perbuatan itu dilakukan), dalam bahasa Latinnya asas "nullum delictum, nulla poena sine praevia lege poenali" atau disingkat "Nullum Delictum".17

Hal ini diatur dalam Pasal 1 ayat (1) KUHP "tiada suatu peristiwa dapat dipidana, melainkan atas kekuatan ketentuan undang-undang, yang berlaku terdahulu dari peristiwa itu". Asas ini merupakan jaminan untuk keamanan hukum dan melindungi orang-orang terhadap perbuatan sewenang-wenang dari hakim. ${ }^{18}$

Merujuk pada asas legalitas tersebut, maka perlu pengujian terhadap pengguna jasa prostitusi apakah termasuk tindak pidana atau tidak. Kemudian agar suatu perbuatan itu dapat dihukum, harus memenuhi semua unsur delik yang dirumuskan dalam undang-undang. Merujuk pada asas legalitas, apabila dikaitkan dengan perbuatan prostitusi terkhususnya terhadap pengguna jasa prostitusi, dapat dilihat dari sisi hukum apakah pengguna jasa prostitusi tersebut dapat dijerat secara pidana atau tidak.

Pengaturan dalam KUHP hanya ada beberapa Pasal yang berkaitan dengan perbuatan prostitusi, yaitu Pasal 296 dan Pasal 506:

Pasal 296 menyatakan:

Barang siapa dengan sengaja menyebabkan atau memudahkan perbuatan cabul oleh orang lain, dan menjadikannya sebagai pencaharian atau kebiasaan, diancam dengan pidana penjara paling lama satu tahun empat bulan atau denda paling banyak lima belas ribu rupiah.

Sedangkan Pasal 506 KUHP menyatakan:

Barang siapa menarik keuntungan dari perbuatan cabul seseorang wanita dan menjadikannya sebagai pelacur, diancam dengan pidana kurungan paling lama satu tahun.

Berdasarkan Pasal 296 dan Pasal 506 bahwa dapat diketahui hukum pidana saat ini dalam KUHP hanya mengkategorikan prostitusi sebagai tindak pidana terhadap pihak perantaranya saja yaitu kepada pemilik rumah bordil, mucikari dan makelar atau calo dari perbuatan pelacuran tersebut saja, tidak untuk pengguna jasa prostitusinya. Hal ini kepolisian hanya dapat melakukan tindakan hukum terhadap mucikarinya saja, ketika perbuatan tersebut terdapat mucikarinya, namun apabila perbuatan prostitusi tersebut secara individu dan tidak ada mucikarinya, maka tidak dapat mempidana pihak-pihak prostitusi tersebut.

16 E.Y. Kanter dan S.R. Sianturi, Asas-asas Hukum Pidana di Indonesia dan Penerapannya, Storia Grafika, Jakarta, 2002, hlm. 249.

17 Monang Siahaan, Pembaruan Hukum Pidana Indonesia, Grasindo, Jakarta, 2016, hlm. 180.

18 Monang Siahaan, Pembaruan Hukum Pidana Indonesia, hlm. 180. 
Selain aturan yang terdapat dalam KUHP, ketentuan lain yang berkaitan dengan praktik prostitusi adalah Undang-Undang Nomor 21 Tahun 2007 tentang Pemberantasan Tindak Pidana Perdagangan Orang (TPPO) dan/atau Namun dalam Undang-Undang TPPO hanya dapat mempidana seseorang yang mendapatkan keuntungan dari perdagangan orang (mucikari). Akan tetapi sanksi pidana bagi pelaku prostitusi tidak dapat dipidana apabila perbuatan tersebut dilakukan secara sukarela tanpa pelakunya merasa tereksploitasi. Karena undang-undang tersebut secara spesifik mengatur perdagangan orangberdasarkan Pasal 1 ayat (1) Undang-Undang Nomor 21 Tahun 2007 tentang Pemberantasan Tindak Pidana Perdagangan Orang (TPPO) yaitu:

Tindakan perekrutan, pengangkutan, penampungan, pengiriman, pemindahan, atau penerimaan seseorang dengan ancaman kekerasan, penggunaan kekerasan, penculikan, penyekapan, pemalsuan, penipuan, penyalahgunaan kekuasaan, atau posisi rentan, penjeratan utang atau member bayaran atau manfaat, sehingga memperoleh persetujuan dari orang yang memegang kendali atas orang lain tersebut, baik yang dilakukan di dalam negara maupun antar negara, untuk tujuan eksploitasi atau mengakibatkan tereksploitasi.

Penjelasan di atas dapat disimpulkan bahwa Undang-Undang Tindak Pidana Perdagangan Orang tidak dapat menjerat hukum terhadap pengguna jasa prostitusinya karena tidak ada aturan yang mengatur. Sedangkan ketentuan lain yaitu UndangUndang Nomor 35 Tahun 2014 tentang Perubahan Atas Undang-Undang Nomor 23 Tahun 2002 tentang Perlindungan Anak hanya mempidana pengguna dari eksploitasi seksual Anak.

Selain dari pada itu terdapat berbagai macam cara untuk melakukan perbuatan prostitusi, salah satunya yaitu secara online, biasa dikenal dengan prostitusi online. Aturan yang berkaitan dengan prostitusi online tersebut terdapat dalam UndangUndang No.11 tahun 2008 tentang Informasi dan Transaksi Elektronik.

Perbuatan prostitusi dapat dikatakan sebagai perbuatan zina yang termasuk dalam Pasal 284 tentang perzinahan. Perzinahan dalam pengertian hukum, yakni persetubuhan atau hubungan badan secara seksual antara seorang yang telah berkeluarga dengan orang lain yang bukan istri atau suaminya. Penggunaan pasal 284 hanya dapat berlaku pada salah satu pengguna jasa prostitusi yang telah terikat perkawinan, sedangkan apabila pengguna jasa prostitusi ini belum terikat dengan perkawinan maka tidak dapat diterapkan pasal tersebut. Selain itu, pasal 284 merupakan delik absolut yang artinya tidak dapat dituntut apabila tidak ada pengaduan dari pihak suami dan istri yang dirugikan .

Apabila perzinaan dijadikan delik aduan, maka peluang untuk terjadinya perzinaan akan lebih besar seperti pandangan Barda Nawawi Arief, bahwa :

Dengan memberinya peluang adanya perzinaan, jelas hal ini akan menumbuhsuburkan dunia pelacuran. Hubungan kausal/korelasi antara keduanya sesuai dengan hukum ekonomi; semakin banyak permintaan/kebutuhan tentu semakin banyak penawaran. Semakin suburnya usaha pelacuran, berarti semakin besar peluang menyebarnya penyakit kotor yang membahayakan masyarakat. Memang banyak faktor yang dapat menyebar-luaskan penyakit AIDS, namun sering pula dikemukakan bahwa penyebab utamanya adalah melakukan hubungan seks secara liar di luar pernikahan, khususnya lewat pelacuran. Memang menghadapi masalah sosial ini tidak semata-mata dapat diatasi dengan hukum pidana. Namun apabila 
upaya-upaya lain lewat pendidikan moral kesehatan masyarakat lainnya belum juga memadai, maka dilihat dari sudut kebijakan sosial khususnya dari sudut kebijakan perlindungan masyarakat (social defence policy) mungkin sudah saatnya memanggil dan mengefektifkan hukum pidana untuk menanggulanginya. Ini berarti kebijakan menetapkan delik perzinaan sebagai delik aduan, patut ditinjau kembali. ${ }^{19}$

Adapun pemerintah daerah masing-masing mengambil kebijaksanaan dengan tindakan-tindakan tertentu yang dapat dikategorikan sebagai tindakan represif, dalam arti melakukan tindakan-tindakan terhadap prostitusi yang ada dalam masyarakat, dengan tidak melaksanakan hukum pidana yang masih berlaku melainkan dengan PERDA ataupun suatu kebijakan operasional. ${ }^{20}$ Pengaturan mengenai prostitusi ini juga termuat dalam peraturan daerah yang dibuat oleh Pemerintah Daerah, diantaranya :

\section{PERDA Kab. Indramayu No.7 Tahun 1999}

Diatur pada Pasal 7 bahwa pelaku prostitusi baik laki-laki ataupun perempuan dapat dikenakan sanksi pidana berdasarkan pasal 9 ayat (1) yaitu setiap orang yang melanggar PERDA ini akan diancam paling lama sanksi pidana kurungan enam bulan atau dengan denda paling banyak lima juta rupiah.

2. PERDA Kota Tangerang No.8 Tahun 2005

Berdasarkan ketentuan Pasal 2 ayat (2) PERDA ini bahwa siapapun baik sendiri atau bersama-sama dilarang melakukan perbuatan prostitusi sesuai dengan Pasal 9 ayat (1) apabila terdapat pelanggaran atas PERDA ini akan diancam paling lama pidana kurungan tiga bulan atau denda paling tinggi lima belas juta rupiah.

3. PERDA Prov.DKI Jakarta No.8 Tahun 2007 Tentang Ketertiban Umum.

Kemudian berdasarkan Pasal 42 ayat (2) PERDA ini, siapapun dilarang untuk : a). menyuruh, memfasilitasi, membujuk, memaksa orang lainuntuk menjadi penjaja seks komersial; b). menjadi penjaja seks komersial; c). memakai jasa penjaja seks komersial. Siapapun yang melanggar PERDA ini akan diancam paling singkat pidana kurungan dua puluh hari dan paling lama sembilan puluh hari, atau denda sedikitnya lima ratus ribu rupiah dan paling banyak tiga puluh juta rupiah.

4. PERDA Kota Denpasar No.1 Tahun 2015 Tentang Ketertiban Umum

Pasal 39 ayat (1) setiap orang dilarang : a. melakukan perbuatan prostitusi; b. menawarkan dan/atau menyediakan diri sendiri untuk perbuatan prostitusi; c. menyuruh, memfasilitasi, membujuk, memaksa, menawarkan orang lain untuk melakukan perbuatan prostitusi; dan d. memakai jasa prostitusi.

Sanksi pidananya diatur dalam pasal 58 ayat (2) yaitu: siapapun yang melanggar ketentuan PERDA ini diancam dengan pidana kurungan paling lama 6 (enam) bulan atau denda paling banyak RP.50.000.000 (lima puluh juta rupiah) dan dapat dikenakan sanksi lain dari peraturan perundang-undangan yang berlaku.

5. PERDA Kab. Bandung No.7 Tahun 2016 Tentang Ketertiban Umum dan Ketentraman Masyarakat

19 Barda Nawawi Arief, Bunga Rampai Kebijakan Hukum Pidana Perkembangan Penyusunan Konsep KUHP Baru, Kencana, 2016, hlm. 287.

20 Yesmil Anwar dan Adang, Kriminologi, Refika Aditama, Bandung, 2013, hlm. 358. 
Pasal 26 ayat (2) Siapapun dilarang : a. menawarkan dan/atau menyediakan diri sendiri untuk perbuatan prostitusi; b. menyuruh, memfasilitasi, membujuk, memaksa orang lain untuk melakukan perbuatan prostitusi; dan c. memakai jasa prostitusi.

Ketentuan sanksi pidananya diatur dalam Pasal 32 ayat (2) siapapun yang melanggar ketentuan PERDA ini dapat diancam pidana kurungan paling banyak Rp.50.000.000,00 (lima puluh juta rupiah).

Adapun tindakan tersebut yaitu tindakan razia terhadap pelaku prostitusi (pelacur) yang berada di jalanan. Biasanya tindakan razia dilakukan oleh pihak Kepolisian bekerja sama dengan jawatan sosial, dimana tindak lanjut dari razia tersebut adalah wanita-wanita yang melakukan kehidupan sebagai pelaku prostitusi di jalan-jalan yang berhasil ditangkap dan ditampung di wisma penampungan milik jawatan sosial setempat untuk dididik dengan diberikan kursus keterampilan seperti menjahit dan lain-lain, diberi nasihat-nasihat untuk kemudian dikembalikan ke masyarakat. ${ }^{21}$

Ketentuan PERDA ini menjelaskan bahwa perbuatan prostitusi sudah meresahkan masyarakat, sehingga kegiatan prostitusi seperti membujuk, memfasilitasi, memaksa orang lain untuk menjadi pekerja seks komersial atau yang dikenal dengan sebutan mucikari, menjadi pekerja seks komersial, hingga pengguna jasa prostitusi yang dilakukan kepada wanita tuna susila (WTS) atau pera tuna susila (gigolo) sebagai penikmat jasa pekerja seks komersial yang melakukan hubungan seksual diluar perkawinan yang sah untuk mendapatkan imbalan baik berupa uang, materi maupun jasa merupakan suatu tindak kejahatan. Sehingga dalam PERDA ini, pengguna jasa prostitusi dapat dijerat hukum ketika melakukan perbuatan prostitusi di daerah tersebut.

PERDA yang telah mengatur terkait keseluruhan tentang prostitusi ini merupakan peraturan yang paling tepat dalam menjerat pengguna jasa prostitusi, namun pengaturan ini hanya mengatur secara khusus (lex spesialis) terhadap daerah tertentu saja yang mempunyai pengaturan tersebut, dan tidak dapat diterapkan di daerah lain. Sehingga, masih memberikan celah kepada pengguna jasa prostitusi diluar aturan PERDA tersebut.

Perbuatan pelacuran bagian dari perbuatan zina yang dikategorikan sebagai (crime without victim) bahwa PSK dan pengguna termasuk korban tetapi juga sebagai pelaku dalam perbuatannya sehingga hukum pidana positif di Indonesia saat ini masih belum memberikan kepastian hukum yang adil serta pelakuan yang sama dihadapan hukum sebagaimana yang diamanatkan dalam Undang-Undang Dasar 1945 Pasal $28 \mathrm{D} .^{22}$

Pertanggungjawaban pidana dalam teori menjelaskan bahwa pertanggungjawaban pidana hanya dapat berlaku jika sebelumnya seseorang sudah melakukan tindak pidana. Seperti yang dikatakan Moeljatno bahwa, orang tidak mungkin dipertanggungjawabkan (dijatuhi pidana) kalau tidak melakukan perbuatan pidana. ${ }^{23}$

21 Yesmil Anwar dan Adang, Kriminologi, hlm.358.

22 Lucky Elza Aditya," Urgensi Kriminalisasi Terhadap Pelacuran", hlm.5.

23 Chairul Huda, "Dari 'Tiada Pidana Tanpa Kesalahan", hlm. 20. 
Berkenaan dengan penjelasan Moeljatno, dapat ditarik pengertian bahwa pertanggungjawaban pidana hanya akan berlaku jika sebelumnya sudah pernah ada seseorang yang melakukan tindak pidana. Pada konteks perundangan juga dikatakan bahwa ada tidaknya pidana ditentukan oleh peraturan perundang-undangan, yang diinterpretasikan bahwa tidak ada pertanggungjawaban pidana tanpa aturan hukum yang mengaturnya terlebih dahulu. ${ }^{24}$

Pandangan masyarakat terhadap prostitusi adalah suatu kejahatan. Karena prostitusi merupakan perbuatan yang tidak sesuai dengan nilai-nilai dalam masyarakat dan dapat merugikan masyarakat hingga merusak rasa keadilan untuk masyarakat sehingga kesejahteraan masyarakat terganggu dikarenakan adanya tidak ketertiban sosial di dalamnya. Sehingga perbuatan prostitusi ialah perbuatan kejahatan.

Hal ini juga ditegaskan dalam definisi Rechtdelictten (kejahatan), yaitu perbuatan yang bertentangan dengan keadilan, terlepas apakah perbuatan itu diancam dengan pidana dalam suatu undang-undang atau tidak, jadi yang benar-benar dirasakan oleh masyarakat sebagai hal yang bertentangan dengan keadilan tersebut dapat dikatakan sebagai kejahatan. ${ }^{25}$

Layaknya kejahatan pada umumnya, dalam prostitusi juga terdapat berbagai pihak-pihak yang terlibat dalam pelaksanaannya, dan pada dasarnya memainkan perannya masing-masing. Secara umum yaitu penyedia layanan yang biasa disebut dengan mucikari/germo, calo, pekerja seks komersial yang biasa disebut dengan PSK/pelacur dan pengguna jasa prostitusi. Keempat pelaku tersebut saling berhubungan satu dengan yang lainnya.

Melihat dari berbagai pihak yang berperan dalam kejahatan prostitusi ini, yang bertanggungjawab atas perbuatanya hanya beberapa pihak saja. Pertanggungjawaban pidana terhadap pihak-pihak yang terlibat dalam perbuatan prostitusi belum dapat menjerat hukum seluruh pihaknya, terutama terhadap pengguna jasa prostitusi. Pengguna jasa prostitusi ini dibiarkan begitu saja tanpa adanya hukum yang mengatur secara jelas dan tegas, seolah-olah perbuatannya bukan merupakan hal tercela, sedangkan perbuatan tersebut sudah dikategorikan sebagai suatu kejahatan. Sehingga lahir akibat tuntutan rasa keadilan dan kepastian hukum dari masyarakat yang mempersoalkan terkait pertanggungjawaban pidana para pelaku prostitusi berdasarkan hukum yang berlaku di Indonesia.

Pengguna jasa prostitusi pada dasarnya merupakan orang normal yang mampu bertanggungjawab. Akan tetapi, pengguna jasa prostitusi di Indonesia tidak dapat dipidana secara menyeluruh karena unsur-unsur teori di atas telah menjabarkan kelemahan hukum pidana saat ini.

Hukum yang ada pada saat ini bersifat belum menyeluruh terhadap pemberantasan prostitusi. Seseorang yang menggunakan atau membeli jasa prostitusi tersebut bukan termasuk suatu tindak pidana karena tidak dilarang dalam hukum pidana Indonesia meskipun melanggar dari sudut pandang agama, adat istiadat, dan kesusilaan dalam masyarakat.

\section{Pertanggungjawaban Pidana Terhadap Pengguna Jasa Prostitusi di Swedia Sebagai Wujud Pembaharuan Hukum Pidana di Indonesia}

24 Chairul Huda, "Dari “Tiada Pidana Tanpa Kesalahan”, hlm. 21.

25 Ridwan, Sari Kuliah Perbandingan Hukum Pidana, Untirta Press, Serang, 2017, hlm. 16. 
Kejahatan prostitusi terus mengalami perkembangan. Walaupun di Indonesia sudah banyak terjadi perbuatan prostitusi, namun Indonesia belum memiliki peraturan yang secara tegas mengatur hal itu. Oleh karena itu, hukum positif di Indonesia perlu untuk diperbaharui.

Barda Nawawi Arief menyatakan bahwa :

Pembaharuan hukum pidana (penal reform) merupakan bagian dari kebijakan hukum pidana (penal policy) yang merupakan bagian dari kebijakan penanggulangan kejahatan (criminal policy) dan tak lain merupakan upaya integral dari kebijakan dalam perlindungan masyarakat (social defence policy) dan kebijakan dalam kesejahteraan masyarakat (social welfare policy), maka keseluruhan upaya tersebut harus disesuaikan dnegan tujuan. Tujuan tersebut tidak lain adalah tujuan negara dalam rangka melindungi segenap bangsa Indonesia dan untuk memajukan kesejahteraan umum berdasarkan pancasila dan Undang-Undang Dasar 1945. ${ }^{26}$

Melihat penjelasan tersebut bahwa pembaharuan hukum pidana merupakan bagian dari kebijakan hukum pidana yang dimaksudkan untuk menciptakan peraturan yang lebih baik dan sesuai dengan kondisi atau keadaan yang hidup dalam masyarakat dengan berdasarkan tujuan dari negara yaitu melindungi segenap bangsa Indonesia dan untuk memajukan kesejahteraan umum berdasarkan Pancasila dan UndangUndang Dasar 1945.

Pembaharuan sistem hukum pidana dapat meliputi ruang lingkup yang sangat luas, yaitu mencakup :27

1. Pembaharuan struktur hukum pidana, yang meliputi antara lain pembaharuan atau penaataan institusi/lembaga, system manajemen/tatalaksana dan mekanismenya serta sarana/prasaran pendukung dari sistem penegakan hukum pidana (sistem peradilan pidana);

2. Pembaharuan substansi hukum pidana yang meliputi pembaharuan hukum pidana materiel (KUHP dan UU diluar KUHP), hukum pidana formal (KUHAP) dan hukum pelaksanaan pidana; dan

3. Pembaharuan budaya hukum pidana, yang meliputi antara lain masalah kesadaran hukum, perilaku hukum, pendidikan hukum dan ilmu hukum pidana.

Berdasarkan hal diatas, penulis lebih fokus terhadap pembaharuan substasi hukum pidana yaitu pembaharuan hukum pidana materil dengan metode perbandingan hukum pidana mengenai pertanggungjawban pidana terhadap pengguna jasa prostitusi yang terlibat dalam prostitusi.

Hukum pidana positif di Indonesia saat ini tidak sesuai dengan nilai-nilai yang ada didalam masyarakat. Oleh karena itu,hukum pidana positif di Indonesia perlu untuk diperbaharui, karena jika dikaitkan dengan prostitusi belum ada aturan hukum tentang perbuatan prostitusi terutama terhadap pengguna jasa prostitusi baik dalam KUHP maupun Undang-Undang diluar KUHP.

Hukum pada saat ini yang mengatur delik kesusilaan dalam KUHP masih mempunyai kelemahan secara moral mengingat bahwa pembentukan delik kesusilaan

26 Ferry Fathurokhman, Hukum Pidana Adat Baduy dan Pmebaharuan HUkum Pidana, INCA Publishing, Depok, 2016, hlm.74

27 Ferry Fathurokhman, "Hukum Pidana Adat Baduy", hlm. 72. 
tidak menggunakan nilai dasar atau "the living law" dari masyarakat Indonesia. ${ }^{28}$ Selama ini dalam KUHP dan Undang-Undang diluar KUHP hanya dapat menjerat penyedia tempat dan atau mucikarinya saja, sedangkan untuk pengguna jasa prostitusi ini tidak dapat dijerat hukum.

Untuk melakukan suatu pembaharuan hukum pidana memiliki berbagai macam metode, salah satunya dengan metode perbandingan hukum pidana. Jika dikaitkan dengan prostitusi, beberapa Negara di dunia yang telah memiliki aturan nasional terkait kriminalisasi terhadap pengguna jasa prostitusi dalam upaya pembaharuan hukum pidana di Indonesia diantaranya seperti Negara Swedia sejak tahun 1999 dalam hukum nasionalnya sudah mengatur bahwa pengguna jasa prostitusi dapat dipidana.

Sebagaimana yang telah disinggung diatas bahwa, dalam pertanggungjawaban pidana di Indonesia terhadap pengguna jasa prostitusi tidak ada aturan yang mengaturnya. Berbeda dengan, dalam kebijakan hukum Negara Swedia, pada 1 Januari 1999 memberlakukan Sex Purchase Law. Membeli atau berusaha membeli layanan seksual menjadi tindak pidana yang dapat dihukum dengan denda atau penjara maksimum 6 bulan. Akan tetapi pada saat ini sejak tahun 2011 hukuman tersebut ditambah menjadi 1 tahun penjara. ${ }^{29}$ Aturan tersebut terdapat dalam Swedish Penal Code, chapter 6: Sexual Crimes, Section 11:

"A person who, otherwise than as previously provided in this Chapter, obtains a casual sexual relation in return for payment, shall be sentenced for purchise of sexual service to a fine or imprisonment for at most one year.

The provision of the first paragraph also apply if the payment was promised or given by another person"

(Seseorang yang selain dari yang disebutkan sebelumnya dalam bab ini, melakukan hubungan seksual biasa dengan imbalan pembayaran, akan dihukum karena pembelian layanan seksual dengan denda atau hukuman penjara paling lama satu tahun.

Ketentuan paragraf pertama juga berlaku jika pembayaran dijanjikan atau diberikan oleh orang lain)Berdasarkan uraian tersebut, yang dimaksud dengan seseorang yang selain dari yang disebutkan dalam bab ini adalah yang terdapat dalam Swedish Penal Code Chapter 6 section 1-10 yaitu:

Seperti pemerkosaan, pemaksaan seksual, eksploitasi seksual terhadap anak, seseorang yang melakukan hubungan seksual dengan seorang anak dibawah umur 15 tahun, pelecehan seksual terhadap seorang anak dan pelecehan seksual berat terhadap seorang anak, seseorang yang melakukan hubungan seks dengan anaknya sendiri, eksploitasi anak untuk berpose seksual, pembelian tindakan seksual dari anak, seksual dalam penganiayaan.

Selain dari pada itu, pengguna jasa prostitusi di Swedia juga diberikan sanksi berupa pemberitaan di media massa atau online bagi pelaku prostitusi. Dengan pemberitaan ini, maka dipastikan pelaku prostitusi akan jera. Persentase prostitusi menurun tajam melebihi 50 persen dibandingkan sebelum tahun 1999. Persentase ini meliputi praktik prostitusi di jalanan, rumah-rumah bordil, hotel, maupun apartemen yang transaksinya dilakukan secara langsung atau tidak langsung. Pengadilan akan

\footnotetext{
28 Lucky Elza Aditya, "Urgensi Kriminalisasi Terhadap Pelacuran", hlm.19.

29 Sven-Axel Mansson, The History and Rationale of Swedish Prostitution Policies, Dignity: A journal on sexual Exploitation and Violence, Vol.2, 2017, hlm. 3.
} 
menjatuhkan hukuman bagi pelaku dengan bentuk hukuman berupa kerja sosial, denda, hingga dijebloskan penjara paling lama satu tahun. Terhadap korban (pelaku prostitusi, Swedia memberikan pendidikan, pelatihan, pemberdayaan untuk dapat kembali ke masyarakat, dan rehabilitasi). ${ }^{30}$

Aturan Swedia ini juga dapat berlaku untuk prostitusi pria dan wanita. Membeli layanan seksual pada satu kesempatan sudah cukup untuk dipertanggungjawaban pidananya. $^{31}$

Pertanggungjawaban pidana juga dapat dikenakan terhadap seseorang, selain orang yang memanfaatkan layanan seksual saja, akan tetapi orang yang telah memberikan atau menjanjikan transaksi tetapi belum mendapatkan imbalan atas transaksinya yaitu berupa layanan seksual juga dapat dijerat hukum.Skala hukuman untuk pembelian layanan seksual adalah denda atau hukuman penjara untuk 1 tahun. ${ }^{32}$

Pada tahun 2008, swedia membuat penyelidikan khusus sebagai bagian dari rencana aksi melawan pelacuran dan perdagangan manusia untuk seksual :

Pemerintah Swedia menunjuk komite penyelidikan khusus, yang dikenal sebagai Komite Penyelidikan untuk mengevaluasi larangan terhadap pembelian layanan seksual. Kanselir Kehakiman Anna Skarhed, sebelumnya seorang Hakim Mahkamah Agung, memimpin komite tersebut, dan dibantu oleh tim ahli dan sekretaris. Tujuan komite adalah untuk mengevaluasi larangan terhadap pembelian layanan seksual.Itu ditugaskan menentukan bagaimana larangan berfungsi dalam praktik dan dampak kriminalisasi terhadap kejadian pelacuran dan perdagangan manusia untuk tujuan seksual di Swedia. ${ }^{33}$

Petugas polisi dan pekerja sosial melaporkan bahwa pembeli layanan seksual menjadi lebih hati-hati dan larangan itu telah menyebabkan penurunan permintaan, karena kriminalisasi tersebut. Menurut polisi, pembeli takut ditangkap, tetapi lebih peduli dengan kejahatan itu terekspos kepada keluarga dan kenalan daripada tentang hukuman hukum aktual yang berisiko mereka dapatkan. ${ }^{34}$

Perdagangan manusia untuk tujuan seksual adalah bentuk kejahatan ekonomi serius yang terus berkembang di dunia. Meskipun sulit untuk menilai skala yang tepat dari perdagangan manusia untuk tujuan seksual, di Swedia pembentukan jenis kejahatan ini dianggap jauh lebih kecil dadlam skala perbandingan dengan negaranegara lain yang sebanding. Kepolisian Kriminal Nasional Swedia menjelaskan bahwa larangan pembelian layanan seksual bertindak sebagai penghalang penyelundup perdagangan manusia dan pengadaan yang dipertimbangkan oleh Negara lain untuk membangun diri mereka di Swedia. ${ }^{35}$

Pengaturan tersebut disebut dengan Model Swedia atau Model Nordik, yang berarti bahwa pendekatan yang menempatkan bahwa prostitusi adalah sebuah

30 Mia Amalia,"analisis terhadap tindak pidana prostitusi dihubungkan dengan etika moral serta upaya penanggulangan di kawasan cisarua kampung arab" Jurnal Mimbar Justitia, Volume II, No.02, 2016, hlm. 876.

31 Maria Ahlin, Freethem, "the Swedish Law (on Prostitution)", diakses dari http://www.antiprostitutie.ro/docs/The\%20Swedish\%20Law.pdf, pada tanggal 26 Februari 2019, pukul 21.13, hlm. 5.

32 Ibid.

33 Selected Extracts of the Swedish Government report SOU 2010:49:, "The Ban against the Purchase of Sexual Service. An Evaluation 1999-2008", Swedish Institute, 2010, hlm.2.

34 Maria Ahlin, Freethem "the Swedish Law (on Prostitution)", hlm. 21.

35 Selected extracts of the Swedish Government Report SOU 2010:49, hlm. 9. 
rangkaian kekerasan laki-laki terhadap perempuan. Ini sebuah pendekatan yang mengkriminalkan pembelian seksdan mucikari tetapi mendekriminalisasi orang-orang yang dilacurkan. Model Nordik didapatkan namanyadari negara pertama yang menerapkannya yaitu Swedia. ${ }^{36}$

Prostitusi ini sudah masuk ke dalam ranah bisnis, dimana permintaan itu bersumber pada pengguna jasa prostitusi. Sedangkan PSK sebagai pemenuhan kebutuhan atas permintaan tersebut. Sejalan dengan hukum ekonomi, yakni semakin banyak permintaan/kebutuhan tentu semakin banyak penawaran. Artinya, semakin banyak pengguna jasa prostitusi maka pemenuhan kebutuhan juga meningkat dan tingkat prostitusi juga semakin subur dimasyarakat. Oleh karena itu, perlu ditekankan angka permintaan dalam hal ini pengguna jasa prostitusi seperti yang diterapkan pada Negara Swedia adanya regulasi tentang pengguna jasa prostitusi tanpa perlu mengkriminalisasikan PSKnya. Walaupun aturannya seperti itu, Swedia mampu menekan tingkat prostitusi hingga lebih dari 50\%. Apalagi jika perbuatan PSK juga dapat dikriminalisasikan, tingkat prostitusi akan semakin menurun jika di Indonesia menerapkan hal tersebut. Oleh karena itu, penelitian ini dimaksudkan untuk melakukan pembaharuan hukum pidana yang mengatur secara tegas dan jelas terhadap pengguna jasa prostitusi di Indonesia sehingga dapat menekan angka tingkat prostitusi.

Swedia yang tidak memiliki nilai-nilai dasar seperti Pancasila saja telah memiliki dan melarang adanya perbuatan pengguna jasa prostitusi. Seharusnya, Indonesia yang memiliki nilai-nilai dasar Pancasila memiliki aturan yang tegas dan jelas untuk menjerat pengguna jasa prostitusi. Karena perbuatan pengguna jasa prostitusi telah melanggar nilai-nilai yang terdapat dalam Pancasila.

Selain Negara Swedia, ada pula Negara lain yang mempunyai aturan terhadap pengguna jasa prostitusi, yaitu Negara Finlandia memiliki aturan terkait pengguna jasa prostitusi yang terdapat dalam The Criminal Code of Finland chapter 20, section 8. ${ }^{37}$

Selain Swedia dan Finlandia, pada 13 April 2016, pemerintah Prancis mengeluarkan undang-undang yang bertujuan untuk mengakhiri prostitusi dan memerangi perdagangan manusia yang terkait dengan prostitusi. Perancis mengatur terkait pengguna jasa prostitusi ini yang terdapat dalam :

Law No. 2016-444 (Id.Article 20).Disebutkan bahwa siapa pun yang dinyatakan bersalah sebagai klien pelacuran dapat dihukum dengan denda hingga $€ 1.500$ (sekitar US \$ 1.700). Denda ini dapat ditambah dengan langkah-langkah hukuman lain tertentu, seperti penangguhan SIM atau persyaratan untuk melakukan antara 20 dan 120 jam pelayanan masyarakat. Selain itu, seorang klien pelacuran mungkin diharuskan untuk menghadiri kursus pelatihan kesadaran untuk menyadarkannya terhadap perang melawan pelacuran. Jika pengguna jasa prostitusi tersebut melakukan kesalahan untuk kedua kalinya, maka pelanggar kedua dapat dihukum dengan denda hingga $€ 3.750 .{ }^{38}$

Selain dari Negara Swedia, Finlandia, Perancis, pada tahun 2008 Negara Norwegia juga memiliki aturan hukum terkait pengguna jasa prostitusi, aturan tersebut terdapat dalam :

36 Charlotta Holmstrom dan May-Len Skilbrei, The Swedish Sex Purchase Act: Where Does it Stand?, Oslo Law Review, Volume 4, No. 2-2017, 2017, hlm.3.

37 Procon, 100 Countries and Their Prostitution Policies.

38 Boring Nicolas, France: New Law to Punish prostitution client. 
Section 316 of the Norwegian General Civil Penal Code: The law against buying sexual service. Menurut KUHP Norwegia, menjual layanan seksual adalah legal. Namun, adalah ilegal bagi warga negara Norwegia atau orang yang tinggal di Norwegia atau untuk membeli layanan seksual, baik Norwegia atau di luar negeri. Membeli layanan seksual dapat dihukum dengan denda dan satu tahun penjara. ${ }^{39}$

Ketika ketentuan ini diberlakukan, itu dianggap sebagai hukum yang dimaksudkan untuk "menakuti" orang dari pembelian seks, dan karena adanya aturan tersebut dapat mengurangi permintaan untuk layanan seksual. Intinya adalah menargetkan pembeli. Ketentuan ini merupakan hukum pencegahan, Tidak hanya karena bertentangan dengan nilai-nilai kemanusiaan yang menjadi dasar masyarakat, tetapi juga karena itu merugikan masyarakat individu, keluarga masing-masing dan dapat menimbulkan rasa malu pada semua orang yang terlibat.

Berdasarkan pengaturan terkait pengguna jasa prostitusi diberbagai negara, wawasan yang paling penting tentang masalah pelacuran adalah bahwa perhatian harus diarahkan kepada pembeli. Itu adalah masalah pergeseran perspektif, yang dapat dinyatakan seperti halnya teori ekonomi yaitu semakin banyak permintaan/kebutuhan tentu semakin banyak penawaran. Maka jika tidak ada permintaan tidak akan ada prostitusi.

Sejalan dengan yang dijelaskan oleh Barda Nawawi Arief bahwa pada inti hakikatnya perbandingan hukum, termasuk di dalamnya adalah perbandingan hukum pidana merupakan suatu cara atau metode dalam sebuah penelitian, perbandingan hukum pidana bukan merupakan cabang hukum dan sejenisnya. ${ }^{40}$ Sehubungan dengan ini, maka perbandingan hukum pidana yang telah dijelaskan di atas, akan menjadi sangat penting untuk pertimbangan pembaharuan hukum pidana terhadap pengguna jasa prostitusi secara lebih baik untuk penanggulangan perbuatan prostitusi.

Seperti yang telah dikemukakan oleh Ridwan, bahwa Perbandingan hukum pidana merupakan instrument yang sangat penting guna pendalaman dan pembaharuan hukum pidana, diharapkan dapat secara lebih baik dalam melakukan penggarapan dan pembaharuan hukum pidana. ${ }^{41}$

Berbagai macam aturan hukum yang mengatur terkait perbuatan prostitusi salah satunya melihat ketentuan Peraturan Daerah yang telah dijelaskan, bahwa Peraturan Daerah telah mengatur mengenai sanksi pidana dalam upaya untuk mengkriminalisasi terhadap perbuatan pengguna jasa prostitusi telah menunjukkan bahwa masyarakat Indonesia menghendaki adanya pengaturan perundang-undangan yang mampu dijadikan dasar hukum yang lebih kuat untuk menaggulangi praktik prostitusi di Indonesia.

Upaya untuk mengkriminalisasi terhadap pengguna jasa prostitusi, Sudarto berpendapat bahwa dalam kriminalisasi, harus diperhatikan hal-hal yang pada intinya sebagai berikut: ${ }^{42}$

1. Penggunaan hukum pidana harus memerhatikan tujuan pembangunan nasional, yaitu mewujudkan masyarakat adil dan makmur yang merata materiil

39 Procon, 100 Countries and Their Prostitution Policies.

40 Barda Nawawi Arief, Perbandingan Hukum Pidana, Rajawali Pers, Jakarta, 2015, hlm.3.

41 Ridwan, Sari Kuliah Perbandingan Hukum Pidana, hlm. 1.

42 Barda Nawawi, Bunga Rampai, hlm. 31. 
spiritual berdasarkan Pancasila; sehubungan dengan ini maka (penggunaan) hukum pidana bertujuan untuk menanggulangi kejahatan dan mengadakan pengugeran terhadap tindakan penanggulangan itu sendiri, demi kesejahteraan dan pengayoman masyarakat.

2. Perbuatan yang diusahakan untuk dicegah atau ditanggulangi dengan hukum pidana harus merupakan perbuatan yang tidak dikehendaki, yaitu perbuatan yang mendatangkan kerugian (materiil dan/atau spiritual) atas warga masyarakat.

3. Penggunaan hukum pidana harus pula memperhitungkan prinsip biaya dan hasil (cost and benefit principle).

4. Penggunaan hukum pidana harus pula memerhatikan kapasitas atau kemampuan daya kerja dari badan-badan penegak hukum, yaitu jangan sampai ada kelampauan beban tugas (overbelasting).

Berdasarkan pertimbangan di atas, kriteria kriminalisasi pada umumnya harus memperhatikan sikap dan pandangan masyarakat mengenai patut tercelanya suatu perbuatan tertentu. Sudah jelas bahwa perbuatan prostitusi ini tidak disukai oleh masyarakat karena banyaknya dampak-dampak negatif yang dapat dirasakan oleh masyarakat seperti, menimbulkan dan menyebarluaskan penyakit kelamin dan kulit, memberikan pengaruh demoralisasi kepada lingkungan khususnya anak-anak muda remaja, merusak sendi-sendi kehidupan keluarga, merusak sendi-sendi moral, susila, hukum dan agama, adanya pengeksploitasian manusia oleh manusia lain, dan masih banyak lagi dampak negatif yang dapat dirasakan oleh masyarakat maupun pihakpihak yang terlibat dalam prostitusi.

Sebagaimana yang telah disinggung di atas bahwa untuk mengkriminalisasi pengguna jasa prostitusi tersebut sudah sesuai dengan tujuan pembangunan nasional, yaitu mewujudkan masyarakat adil dan makmur yang merata materiil spiritual berdasarkan Pancasila.

Tujuan pembangunan nasional Indonesia yang berdasarkan pancasila, secara harafiah atau etimologis "Pancasila" berasal dari bahasa Sansekerta, yaitu Panca berarti lima dan Sila berarti batu sendi, alas dasar. Sedangkan di dalam Kamus Besar Bahasa Indonesia, sila berarti aturan yang melatar belakangi perilaku seseorang atau bangsa, kelakuan atau perbuatan yang menurut adab, dasar, akhlak, moral, dengan demikian Pancasila dapat juga diartikan lima aturan/dasar yang melatarbelakangi perilaku seseorang atau bangsa. ${ }^{43}$

Berdasarkan penjelasan di atas maka dalam rangka mewujudkan pembangunan sistem hukum nasional (sistem hukum Pancasila) yang berdasarkan nilai-nilai ketuhanan seperti yang disebutkan dalam sila ke-1 adalah Ketuhanan Yang Maha Esa, jika dikaitkan dalam persoalan terhadap pengguna jasa prostitusi, bahwa perbuatan prostitusi di dalam agama apapun (Agama Islam, Kristen Protestan, Katolik, Hindu, Buddha, Kong $\mathrm{Hu} \mathrm{Cu}$ ) tidak memperbolehkan dalam hal ini adalah perbuatan perzinahan diluar perkawinan secara sah, maka selayaknya perbuatan prostitusi itu tidak dapat ditoleransi oleh masyarakat Indonesia.

43 Sri Endah Wahyuningsih, Urgensi Pembaharuan Hukum Pidana Materiel Indonesia Berdasarkan Nilai-Nilai Ketuhanan Yang Maha Esa, Jurnal Pembaharuan Hukum, Volume 1 No. 1, 2014, hlm.18. 
Selanjutnya dalam Pancasila sila ke-2 adalah kemanusiaan yang adil dan beradab, yang berarti bahwa setiap manusia harus menjunjung nilai-nilai kemanusiaan yang adil dan beradab dalam kehidupan berbangsa dan bernegara. Maka pembangunan manusia sebagai makhluk yang bermartabat paling tinggi perlu adanya penghargaan dan perlakuan yang sama terhadap setiap negara. ${ }^{44}$

Demikian perlu adanya kriminalisasi terhadap pengguna jasa prostitusi, karena ini adalah perbuatan yang telah memiliki banyak dampak negatifnya dan tidak disukai oleh masyarakat. Kriminalisasi ini bertujuan agar manusia dapat mengendalikan naluri seksnya dan melarang penyaluran kebutuhan seksualnya dalam bentuk zina secara komersil.

Pemidanaan terhadap pengguna jasa prostitusi bukan hanya sebagai dasar pembenaran dari pidana yakni pembalasan atas perbuatan yang merugikan dan melanggar norma saja, tetapi harus memperhatikan apa yang ingin dicapai dengan pemidanaan tersebut. Pemidanaan ini harus menjadikan suatu teguran terhadap masyarakat agar memiliki rasa takut untuk melakukan perbuatan prostitusi.

Hal ini diperkuat dilihat dari sudut politik kriminal, salah satu tujuan yang ingin dicapai lewat hukum pidana ialah pencegahan terjadinya tindak pidana, baik dalam arti pencegahan khusus (spesiale preventie) maupun pencegahan umum (generale preventie). ${ }^{45}$

Pidana akan menimbulkan sebuah pencegahan, kesadaran dan memperbaiki moral dalam batin pengguna jasa prostitusi bahwa pembelian seks berbayar adalah perbuatan yang bersifat melawan hukum yang dilarang oleh norma tertulis dan bertentangan dengan nilai-nilai yang terdapat dalam masyarakat, sehingga jika tetap dilakukan maka akan ada pidana yang ia terima.

Berdasarkan uraian di atas, maka dibutuhkan suatu kebijakan hukum yang tepat dalam menanggulangi prostitusi di Indonesia. Kebijakan kriminalisasi serta pembaharuan hukum pidana sudah sangat dibutuhkan terhadap permasalahan ini. Karena dalam norma hukum, norma agama, norma kesusilaan, dan norma hukum perbuatan pelacuran ini merupakan hal yang sangat tercela. Tidak ada alasan bagi pemerintah untuk melakukan pembiaran terhadap praktik prostitusi yang sampai saat ini masih berlangsung.

\section{SIMPULAN}

Pertanggungjawaban pidana terhadap pengguna jasa prostitusi di Indonesia hingga saat ini belum ada ketentuan khusus yang dapat digunakan untuk memidanakan pengguna jasa prostitusi. Adapun Pasal 284 tentang perzinaan yang hanya berlaku pada salah satu pengguna jasa prostitusi yang telah terikat perkawinan, sedangkan apabila pengguna jasa prostitusi ini belum terikat dengan perkawinan maka tidak dapat diterapkan pasal tersebut. Selain itu, pasal 284 merupakan delik absolut yang artinya tidak dapat dituntut apabila tidak ada pengaduan dari pihak suami dan istri yang dirugikan.Sehingga tidak efektif dalam menanggulangi bisnis prostitusi, karena pengguna jasa prostitusi itu sendiri tidak dapat dijerat berdasarkan hukum positif yang ada di Indonesia. Pada saat ini ketentuan pasal yang dapat diberlakukan terhadap pengguna jasa prostitusi diatur

44 Lucky Elza Aditya, "Urgensi Kriminalisasi terhadap Pelacuran”, hlm. 12.

45 Barda Nawawi Arief, "Bunga Rampai”, hlm. 285. 
oleh Peraturan Daerah. Peraturan Daerah di Indonesia adalah peraturan yang paling tepat dalam menjerat pengguna jasa prostitusi. Namun, keberlakuan peraturan tersebut hanya mengatur secara khusus (lex spesialis) terhadap daerah tertentu yang tidak dapat diterapkan di daerah lain selain yang ada aturannya tersebut sehingga masih memberikan celah kepada pengguna jasa prostitusi diluar daerah yang sudah mengatur terkait peraturan tersebut.

Pertanggungjawaban pidana terhadap pengguna jasa prostitusi di Swedia dalam menanggulangi prostitusi memberlakukan Sex Purchase Lawpada tahun 1999 dengan aturannya yang terdapat dalam Swedish Penal Code, chapter 6: Sexual Crimes, Section 11, bahwa membeli atau berusaha membeli layanan seksual menjadi tindak pidana yang dapat dihukum dengan denda atau penjara maksimum 6 bulan. Akan tetapi pada saat ini sejak tahun 2011 hukuman tersebut ditambah menjadi 1 tahun penjara.Adapun negara lain yang mengikuti aturan Swedia yaitu negara Norwegia dan Perancis dengan memberlakukan aturan yang sama dalam menanggulangi prostitusi, yaitu menjerat hukum terhadap pengguna jasa prostitusi. Sehingga aturan tersebut dapat mengurangi tingkat kejahatan prostitusi. Perbandingan hukum pidana yang telah dijelaskan di atas, akan menjadi sangat penting untuk pertimbangan pembaharuan hukum pidana terhadap pengguna jasa prostitusi secara lebih baik untuk penanggulangan perbuatan prostitusi.

\section{DAFTAR PUSTAKA}

\section{Dokumen Hukum:}

Kabupaten Bandung, Peraturan Daerah Nomor 7 Tahun 2016 Tentang Ketertiban Umum dan Ketentraman Masyarakat.

Kabupaten Indramayu, Peraturan Daerah Nomor 7 Tahun 1999.

Kitab Undang-Undang Hukum Pidana.

Kota Denpasar, Peraturan Daerah Nomor 1 Tahun 2015 Tentang Ketertiban Umum.

Kota Tangerang, Peraturan Daerah Nomor 8 Tahun 2005.

Provinsi Daerah Khusus Ibukota Jakarta, Peraturan Daerah Nomor 8 Tahun 2007.

Republik Indonesia, Undang-Undang tentang Informasi dan Transaksi Elektronik, Nomor 11 Tahun 2009.

Republik Indonesia,Undang-Undang tentang Pemberantasan Tindak Pidana Perdagangan Orang, Nomor 21 Tahun 2007.

Swedish Penal Code

Buku :

A.S Alam dan Amir Ilyas, Kriminologi Suatu Pengantar, Kencana, Jakarta, 2018. 
Barda Nawawi Arief, Bunga Rampai Kebijakan Hukum Pidana Perkembangan Penyusunan Konsep KUHP Baru, Kencana, 2016.

Barda Nawawi Arief, Perbandingan Hukum Pidana, Rajawali Pers, Jakarta, 2015.

Chairul Huda, "Dari 'Tiada Pidana Tanpa Kesalahan Menuju Kepada 'Tiada Pertanggungjawaban Pidana Tanpa Kesalahan”, Kencana, Jakarta, 2011.

E.Y. Kanter dan S.R. Sianturi, Asas-asas Hukum Pidana di Indonesia dan Penerapannya, Storia Grafika, Jakarta, 2002.

Ferry Fathurokhman, Hukum Pidana Adat Baduy dan Pmebaharuan HUkum Pidana, INCA Publishing, Depok, 2016.

Kartini Kartono, Patologi Sosial, PT Raja Grafindo Persada, Jakarta, 2005.

Leden Marpaung, Kejahatan Terhadap Kesusilaan Dan Masalah Prevensinya, Sinar Grafika, Jakarta, 2008.

Lucky Elza Aditya, Urgensi Kriminalisasi Terhadap Pelacuran dalam Pembaharuan Hukum Pidana di Indonesia, Jurnal Hukum, 2016.

Monang Siahaan, Pembaruan Hukum Pidana Indonesia, Grasindo, Jakarta, 2016.

Paisol Burlian, Patologi Sosial, PT Bumi Aksara, Jakarta, 2016.

Ridwan, Sari Kuliah Perbandingan Hukum Pidana, Untirta Press, Serang, 2017.

Yesmil Anwar dan Adang, Kriminologi,Refika Aditama, Bandung, 2013.

\section{Jurnal/ Majalah Ilmiah}

Charlotta Holmstrom dan May-Len Skilbrei, The Swedish Sex Purchase Act: Where Does it Stand?, Oslo Law Review, Volume 4, No. 2-2017, 2017.

Max Waltman, Sweden's prohiibition of purchase of sex: The law's reason, impact and potential, Departmen of political Science, Women's Studies International forum 34, 2011.

Mia Amalia,"analisis terhadap tindak pidana prostitusi dihubungkan dengan etika moral serta upaya penanggulangan di kawasan cisarua kampung arab" Jurnal Mimbar Justitia, Volume II, No.02, 2016.

Selected Extracts of the Swedish Government report SOU 2010:49:, "The Ban against the Purchase of Sexual Service. An Evaluation 1999-2008", Swedish Institute, 2010.

Sri Endah Wahyuningsih, Urgensi Pembaharuan Hukum Pidana Materiel Indonesia Berdasarkan Nilai-Nilai Ketuhanan Yang Maha Esa, Jurnal Pembaharuan Hukum, Volume 1 No. 1, 2014. 
Sven-Axel Mansson, The History and Rationale of Swedish Prostitution Policies, Dignity: A journal on sexual Exploitation and Violence, Vol.2, 2017.

Trias Palupi Kurnianingrum, Politik Hukum Terhadap Terhadap Tindak Pidana Prostitusi, Bidang Hukum Info Singkat, Vol. XI No.01, 2019.

Internet:

http://www.antiprostitutie.ro/docs/The\%20Swedish\%20Law.pdf

https://prostitution.procon.org/view.resource.php?resourceID=000772

https:// www. hidayatullah.com /berita /nasional /read /2015/05/21/70066/ sudahsaatnya pemerintah-dan-dpr-rumuskan-ruu-anti-prostitusi.html

https://www.loc.gov/law/foreign-news/article/france-new-law-to-punis-prostitution -clients/ 